P. F. Kendall ; that on the Irish elk in the Isle of Man, by P. M. C. Kermode; and on geological photographs, by Prof. W. W. Watts.

The final meeting of the section on Wednesday was devoted to a joint discussion with Section $\mathrm{H}$, on the first traces of man in North America, in which the President of the Association, Profs. Putnam, McGee and Claypole, and Drs. Dawson and Spencer took part. Though no definite conclusion was reached, the general feeling of the meeting seemed to be against the high antiquity of the reputed finds in the Trenton gravels.

This completed the work of the section, and brought an extremely busy week to a successful termination. The Toronto meeting of the British Association, so far as Section C is concerned, must be regarded as well above the average of recent meetings, both in the quantity and quality of its work, and as one which all the geologists present will remember both with profit and pleasure.

\section{ANTHROPOLOGY AT THE BRITISH} ASSOCIATION.

NATURALLY most of the papers read before Section $H$ related to American anthropology ; the following abstracts give some idea of the more important of the communications.

Miss A. C. Fletcher, who has a long and intimate acquaintance with the Omaha, gave a couple of papers on the Scalplock and the import of the totem among that tribe. Her sympathetic studies have thrown considerable light upon the religious conceptions of these people, and she has demonstrated that they can compose highly dramatic songs and music. In the legend of the Sacred Pole of the Omahas, we are told, "The people felt themselves weak and poor. Then the old men gathered together and said, 'Let us make our children cry to Wakonda.' So all the parents took their children, covered their faces with soft clay, and sent them forth to lonely places. The old man said, "You shall go forth to cry to Wakonda. When on the hills you shall not ask for any particular thing; whatever is good, that may Wakonda give." Thenceforth on arriving at puberty the youth went fasting among the hills till he fell into a trance; whatever he then beheld in his sleep would be the special medium through which he could receive supernatural aid. This was his personal totem. He then banded himself with those who had received simila visions, and who formed a brotherhood or religious society. These were probably the most primitive social organisations. A further integration resulted in the grouping of brotherhoods into gentes, who practised exogamy and traced descent through the father. Each gens had its totem, which was probably that of the original founder of the gens.

The gentile totem gave no immediate hold upon the supernatural, as did the individual totem to its possessor; it served solely as a mark that the individual belonged to a definite kinship group from which he could never sever himself without incurring supernatural pnnishment.

The child entered into the gens by means of the ceremony of hair-cutting. As recently practised this rite consisted of two parts, of which the first was confined to boys. A child was presented by his mother to Thunder priest with the words, "I desire my child to walk long upon the earth, I desire him to be satisfied with much food, we seek your protection, we hold to you for strength." While singing a song the priest cut a tuft of hair from the crown of the head, and laid it away in the sacred case. The hair typified the life of the boy, which was thus symbolically entrusted to the safe-keeping of the Thunder god. The child thenceforth passes out of the simple relation he bears to his parents, and by this act is re-born into the tribe and becomes a recognised member of the tribe. The sign of this consecration is the small lock of braided hair, which is isolated from the rest, and to which is fastened the talisman and the war honours worn by the warrior. It was this lock that was cut from the head of a slain enemy and formed the central object in the triumph ceremonies, since it pre-eminently represented the life of the vanquished enemy. The second part was common to all children. In a symbolic ceremony the child was turned in the four quarters in order to place it in relation with the elements, and thus to ensure long life and prosperity.

Probably the turning ceremony was the more primitive portion, so that the sequence may have been much as follows : A child was put into harmonious relation with its environment by the rite of the "turning of the child." Then a boy was placed in the safe-keeping of the Thunder god, by means of the "hair-cutting" rite, that he might become a brave defender of his people. The need of the assistance of supernatural forces led to the "vision rite," with its consequent totem. Those having the same totem naturally formed brotherhoods, and which acknowledged spiritual affinities, and lastly kinship was recognised and relatives were bound together by a common totem, and the restrictions of a common tabu. This important paper will shortly be printed in full by the Anthropological Institute.

Mr. C. Hill Tout presented a long folk-tale, entitled "Sqaktktquacht, or the Benign-Faced"-an interesting hero-tale of a clever younger brother who went about doing good. He was the youngest of three brothers, who were the children of the red-headed woodpecker and his wife, the black bear. This saga will be published by the Folk-lore Society.

A legend concerning Scar-face, which is believed by the Algonquian Blackfeet to explain the origin of their principal sacred ceremonies, was sent by Mr. R. N. Wilson. So much ritual has reference to this myth, and so many observances are founded upon it, that the student of Indian religious thought may accept it as one of the most significant and instructive of their legends. A beautiful Indian girl refused many suitors, but promised to marry one young man if the scar that disfigured his face could be removed. After a long journey he cane to where the Sun lived with his wife, the Moon; their son, the Morning Star, befriended Scar-face. The Sun healed him and retained him until he had been taught many religious ceremonies. Eventually he returned home, married the girl, and taught the ceremonies to his tribe, and the sun, as he had promised, was kind to the people and heard their prayers. Mr. Wilson's other paper gave a detailed account of Blackfoot Sun-offerings. The tribal religious ceremonies are performed by "prayerful" men; they are not members of any society, but simply individuals of an extremely religious temperament gifted with a good memory. There is no medical priesthood, as has been inaccurately stated. The Sun is pre-eminently the Blackfoot divinity; they may have had more ancient deities, but the "Creator" was never heard of by them until the advent of the missionaries. An account of the life of the Blackfoot women was given by the Rev. J. Maclean. According to Mr. Stansbury Hagar, who presented a paper on the star-lore of the Micmacs of Nova Scotia, the Micmacs believe the stars to be the camp fires of the inhabitants of the sky. The larger fires are before the dwellings of the chiefs, and around them are grouped the lesser lights of the people who bear the same toten name. The Milky Way is the road between heaven and earth. The four stars of the body of the Plough are known as the Bear. He is pursued by seven birds (the three stars of the Plough-handle, Arcturus and $\gamma, \epsilon$, and $v$ of Böotes). Near the second of these hunters is a faint star representing the kettle in which the bear is to be cooked. Behind them the Northern Crown with $\mu$ and $\nu$ of Böotes form a typical den. In the spring the bear is seen climbing out of his den; in summer he runs across the sky; in the fall, overtaken by his pursuers, he is wounded with an arrow and totters to the ground; in winter he lies dead upon his back, but with the following spring returns to life, and so the cycle continues eternally.

Dr. W. J. McGee gave a graphic account of the Seri Indians of the Gulf of California. This very ancient tribe has been so isolated that it had never before been studied. These cannibals are extremely active and warlike; they use poisoned arrows, and owing to their bellicose disposition they are now nearly extinct. They are more distinctly matriarchal than any other tribe, and were originally monogamous, though now they are polygamous. They live entirely by fishing and the chase, and have no agriculture. Their implements are natural stones, which by use may become pounded into more serviceable shapes; for these the term "protolithic" was suggested. A cultural art has been but recently acquired, as there is no name in general use for the chipped arrow-points that they now employ.

The Kootenays and Salishans of British Columbia were described by Dr. A. F. Chamberlain; though allied in many respects, they belong to two distinct linguistic stocks. The former are intensely democratic and without complicated secret societies or totemistic clans. Sun-worship is strongly developed among them. A large series of interesting Kootenay drawings was exhibited by the author.

A summary of the twelfth report of the Committee appointed to investigate the North-western tribes of Canada, by

NO. [455, VOL. 56] 
Dr. Franz Boas, was read. This closes a very valuable piece of work which was instigated at the first meeting of the Association in Canada.

Mr. E. Sidney Hartland gave a comparative account of hutburial among the American aborigines and other peoples, and its probable significance. The origin of the custom must be sought for in the savage idea of kinship, and in the desire to retain within the kin the deceased and all his power and virtues.

The papers on physical anthropology, or somatology, as our American colleagues call it, were four in number, the most important being two papers by Prof. A. Macalister. In dealing with the causes of brachycephaly, he'pointed out that those brain areas are the first to increase which will be earliest called upon to work; thus the area which presides over the skilled movements of the arm develops before that which is connected with similar movements of the leg. The central parietal and temporal lobes grow quickest, and thus in the majority of cases we find an infantile brachycephaly. By the end of the first dentition the frontal length and parietal height increase. About the end of the first year the brain ceases to be free and untrammelled by its envelope, and a contest begins between brain and bone. The hitherto broad open sulci become narrowed and linear. In the English child the change from brachycephalism to mesaticephalism takes place shortly after completing the first dentition. Two types of brachycephaly may be distinguished : (I) Primary, due to the retention of fotal proportions of the components of the brain, and hence short-headedness accompanied by microcephaly. (2) The secondary brachycephaly is due to increased frontal growth, and is usually associated with megacephaly. The second paper gave a résumé of a study of the brains of several Australian aborigines, and exhibited a number of photographs and drawings. He demonstrated that these brains were not deficient in those areas that were implicated in regulating the movements of the limbs, or in the sensory centres; but that there was a disproportionate lack of development of those regions which are known as the association centres.

In a paper detailing an experimental analysis of certain correlations of mental and physical reactions, Prof. Lightner Witmer gave the following statistics relative to rate of movements.

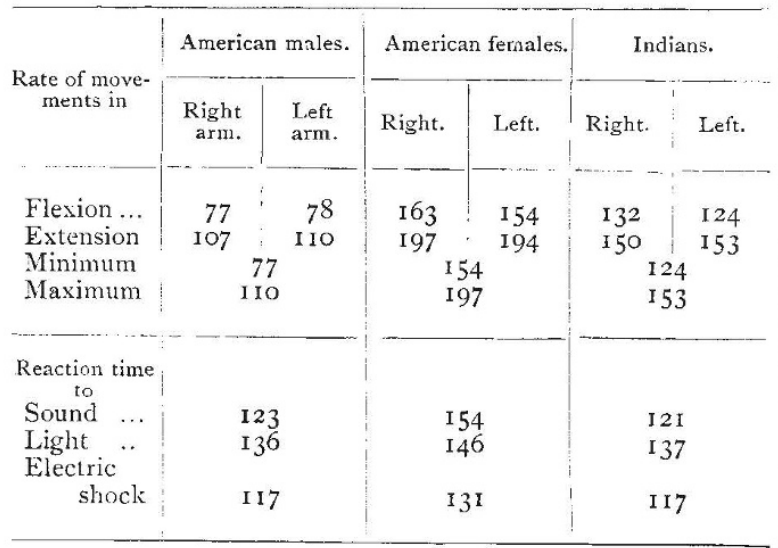

He stated as the results of his experiments, that women were deficient in will power, and do not know how to move so rapidly as men. They also felt more responsibility, while making these experiments, that is, they were more self-conscious. When experiments on sensation for pain were made, there was a tendency for the females to anticipate the sensation, and for the men to deny they felt it at all.

A prominent feature of the session were two discussions, in which the American anthropologists present took a prominent part. The first was on the evidences of American-A siatic contact, and the second was a joint discussion with Section C (Geology) on the first traces of man in the New World. The former was led off by Prof. Putnam giving an account of the origin, aims and organisation of the Jesup expedition to the North Pacific. The object of this extremely important and well-planned expedition is to minutely study the natives of the North-west coast of Canada, those of Alaska and of the corre. sponding coasts of Siberia, and thus to endeavour to gain accurate data towards the solution of the problem of the origin of the
American aborigines. The funds for the expedition, which will be six years in the field, have been supplied through the munificence of Mr. Jesup of New York. The discussion was very animated, and was joined in by the President of the Section, Messrs. Morse, Cushing, McGee and Chamberlain. Prof. Morse argued strongly against any cultural influence between Asia and America, appealing to the distinctness in the pottery, roofing tiles, method of arrow release, \&c., and to the absence in America of the thumb-ring in archery, of the chop-sticks, plough, potter's-wheel, and tea. Cushing argued on the same side, though he believes in a primitive Asiatic origin of the Indians. IIe said if there is a science of anthropology it must be demonstrable that the development of man is according to certain fixed laws, and hence there must be some similarity between different peoples in an analogous stage of culture. In his reply Putnam referred to the distribution of jadite and nephrite implements, and still maintained that there had been more Asiatic influence than most of the speakers admitted.

Not less interesting was the discussion of the antiquity of man in America. This was opened by Prof. F. W. Putnam, who gave an account of the excavations in the Trenton gravels, and of the argillite implements that were found in the lower beds. Prof. E. W. Claypole narrated the discovery of a polished stone implement in the Drift of Ohio ( $c f$. NATURE, vol. Iv. p. 350). Sir John Evans argued that the Trenton finds were all neolithic, and that palæolithic forms were absent from America, though widely spread over the Old World. The true test of a Palæolithic age was the occurrence of animals now extinct. Dr. J. W. Spencer stated that the Lafayette beds followed the Glacial Period, as they contain some re-arranged glacial deposits; then came a period of elevation and denudation, in which the Columbian beds were deposited. Later there were several oscillations of level, during some of which the Trenton gravels were formed. The Trenton gravels may be older than the Falls of Niagara (to which he gave 32,000 years), and he believed they were deposited between 5000 and 50,000 years ago. Dr. McGee believed that the gravels were a wind-blown formation, and stated that Prof. Holmes had failed to find a single artificial object in the undisturbed Trenton gravels, but such objects were found in the talus. Few geologists think implements occur in the gravels. He did not lay much stress on the argument based on the argel. lite implements. Argellite quarries have long been worked by the Algonquins, and plenty of their rejects have been considered as palæeoliths. Prof. Putnam, in his reply, said Sir John Evans was wrong in supposing that neoliths were found in the gravels. The various forms of European palæoliths could be easily matched in numbers in America; but it must be remembered that the European examples are made of flint, but as there is no true flint in America we must not expect a very close correspondence. He again emphasised the preponderance of argellite implements in the lower beds, and alluded to the presence of 99 per cent. of argellite implements in the oldest parts of the shell-heaps of New Jersey.

The genesis of implement-making was the subject of a thoughtful and suggestive essay by F. H. Cushing. He believed that anthropoidal man, who arose somewhere about the Indian Ocean, was coaxed down from the trees by the abundance of food along the shores of the sea, and there, by his own domestication, sowed seeds for variation. Manual dexterity set at naught all the effects of previous evolution, and henceforth evolution became more psychical than physical. As a psychic effect of the upright position, the nascent human beings now looked, for the first time, into the face and eyes of their mates, and conscious love was begotten, then volitional selection began to replace mere sexual selection, and language became possible. For a long period man was "prelithic," and supplemented his teeth and nails with the fangs and claws of wild animals. Stones were picked up and used as occasion required without any preliminary dressing. At first, judging from the actions of monkeys and children, the bones and nuts were broken upon the stones; later, stones were used as crushing or breaking implements. Some of the bruised stones were found to be more effective than others, and these would be treasured, and soon it would occur to people to intentionally fracture stones so as to resemble these. It is possible that some of the earliest implements to be manufactured were made in imitation of the sharks' teeth that they picked up on the shore and used as implements. In employing flint implements on bone or horn it would be discovered that the bone actually worked the flint, and so the removal of flakes by pressure would be found to be more effectual than by hammering, and 
thus the neolithic technique was arrived at and perfected. Certainly some chipped tools would be worn smooth by use ; and if these proved more useful, the actual process would be definitely repeated. In early Palæolithic times man made an important conquest and captured fire, which he kept and fed to protect himself from wild animals and from cold. The domestication of fire was the beginning of the conquest of nature. Later a tacit understanding arose between primitive man and the dog. Mr. Cushing gave a demonstration on some of the early stages of stone implement-making in illustration of his paper.

Several lantern demonstrations were given in the afternoons, among which may be noted the following:- "The Lake.Viliage of Glastonbury and its Place among the Lake-Dwellings of Europe," by Dr. R. Munro; "Some Old-World Harvest Customs," by F. T. Elworthy ; "The Evolution of the Cart and Irish Car," by Prof. A. C. Haddon; "The Kafirs of Kafiristan," by Sir George Robertson ; and "The Mangyans and Tagbanuas of the Philippine Islands," by Prof. Dean C. Worcester.

The sectional meeting was very successful, and it was a great pleasure to the British anthropologists to meet those of their Canadian and American colleagues who attended the meeting. It was a memorable occasion for the interchange of cordial friendship and valuable information.

\section{UNIVERSITY AND EDUCATIONAL INTELLIGENCE.}

THE current number of the Chemical News (September ro) is devoted to descriptions of courses in chemistry at British Uni. versities and Colleges. In a brief introduction to this information, reference is made to " the recognised superiority of German chemists in the quantity of research yearly executed," and attention is called to a pamphlet in which Prof. Dr. F. Fischer recommends that the position in technical chemistry which Germany occupies in comparison with other countries be further extended and secured. It appears that there are in Germany four thousand technical chemists, exclusive of about two hundred others, who study chemistry from a purely scientific point of view.

THE I897-98 Programme of Technological Examinations conducted by the City and Guilds of London Institute, includ. ing regulations for the registration and inspection of classes in technology and manual training, has just come to hand. Year by year, we are glad to remark, this publication increases in size and value. Syllabuses are given of the sixty-seven technolugical subjects in which the Institute holds annual examinations, and helpful lists of works of reference are appended to them. The questions set in this year's examinations are all printed in the Programme, and they show that the Institute is working wisely and well for the advancement of technical education.

\section{SCIENTIFIC SERIALS.}

Bulletin of the American Mathematical Society, July.Newton's theory of kinetics, by W. H. Macaulay, is a dis. cussion of Newton's Scholium to the "definitiones" in the "Principia." Galileo, in his study of the motions of falling bodies and projectiles relative to the earth, though he eliminated the effects of friction and of the resistance of the air, did not introduce any correction involving the earth's rotation. Mr. Macaulay, after referring to Newton's letter to Hooke (Ball, "Essay on Newton's Principia," p. I42), summarises the chief points laid down in Newton's first and second chapters, and notices how difficult Newton's task was, and attempts to clear away some of the difficulties.-The decomposition of modular systems of rank $n$ in $n$ variables is a paper presented by Prof. E. H. Moore to the Chicago section of the American Mathematical Society. - An interesting note upon the biquadratic, entitled "On a solution of the biquadratic which combines the mathods of Descartes and Euler," by Dr. McClintock, read at the May meeting of the Society, employs a resolution which is new to us.-Dr. L. E. Dickson contributes a paper on higher irreducible congruences, which in part runs on parallel lines with the "beautiful" developments of Serret " Algèbre Supérieure"), and in part is quite independent and so is worked out in some detail.--Prof. Van Vleck gives an extended review of Dr. Max Stegemann's editions of Kiepert's "Grundriss der Differential- und Integral-Rechnung " (the former in its seventh and the latter in its sixth edition). The work, with some slight blemishes, appears to be a most valuable work of reference, and it is to be hoped that its good points may be made available to
English students. -A short notice, by Dr. Stabler, follows of A. Arnaudeau's "Projet de Table de Triangulaires de I à $100,000 . " \quad E$. de Joncourt's tables (published at the Hague in I762) go from $n=\mathrm{I}$ to $n=20,000$ in the formula $\frac{1}{2} n(n+\mathrm{I})$. The present tables " are a valuable and interesting addition to the tables now in existence for facilitating multiplication," and are "a great advance over any previously published table of triangular numbers."-Notes, a long list of new publications, list of papers read before the Society (giving places of publication of the same), and index to the volume close the number.

IN the Fournal of Botany for August, Messrs. W. and G. S. West complete their revision of Welwitsch's "African Fresh. water Algæ," a collection which has proved remarkably rich in new forms, including a very large number of new species and not a few new genera. The collection comprises 300 species distributed over 77 genera. - In the number for September, $\mathrm{Mr}$. F. Townsend commends a monograph of the British species of Euphrasia, founded on Wettstein's classical monograph of the genus.-Mr. J. Lloyd Williams records the interesting discovery that the antherozoids or pollinoids of Dictyota and Taonia are not, as has hitherto been supposed, immotile, but are provided with cilia and endowed with motion.

\section{SOCIETIES AND ACADEMIES}

PARIS.

Academy of Sciences, September 6.-M. A. Chatin in the chair.-On the number and symmetry of the fibro-vascular bundles as a measure of the organic perfection of vegetable species, by M. Ad. Chatin. This paper treats of the perigynous Ciamopetale, the hypogynous Gamopetale or Corolliflore having being considered in a previous communication. - On Bessel's functions $\mathrm{O}^{n}(x)$ and $\mathrm{S}^{n}(x)$, by M. L. Crelier.-On the hypocycloid with three cusps, by M. Paul Serret.-The magnetic deviation of the kathode rays and X-rays, by M. G. de Metz. The author continues his study of the magnetic deviation of these rays and, under different experimental conditions, obtains results similar to those described in a preceding note. - Influence of the X-rays on the luminosity of gases, by M. A. de Hemptinne. The action of electric vibrations causes gases to become luminous at a low pressure, but if the gas is, at the same time, submitted to the influence of the X-rays the luminosity appears at considerably higher pressures. Numbers are given for hydrogen and oxygen gases, and for a few organic compounds.-The composition of potatoes, by M. Ballard. Analyses of a number of varieties are given. The amount of water is found to be closely connected with the nature of the soil, and to be independent of the variety and the size of the tuber.

\section{CONTENTS.}

PAGE

A System of Medicine. By F. W. T. . . . . . 465 Anthropology versus Etymology . . . . . . . . . . 466 Our Book shelf :-

Bateman : "The Vivarium."-R. L. . . . . . . 467

"Geological Survey of Canada" . . . . . . . . 467

Sonnenschein : "A Bibliography of Science" . . . . 468

Letters to the Editor:-

Zeeman's Phenomenon.-Prof. Geo. Fras. Fitzgerald, F.R.S.

Coccoliths in our Coastal Waters. (Illustrated.) Dr. J. Joly, F.R.S., and Dr. H. H. Dixon . . A Bright Meteor.-Prof. J. P. O'Reilly . . . . . 469

The Centipede-Whale.-W. F. Sinclair . . . . 470

\section{Notes}

Our Astronomical column:-

The Disintegration of Comets . . . . . . . . . . 473

Forecast of the November Meteor Shower . . . . . 473

The Relationship of Physiology, Pharmacology,

Pathology, and Practical Medicine. By Dr. T. Lauder Brunton, F.R.S.

The British Association. By Prof. W. A. Herdman,

F.R.S.

Section K.-Botany.-Opening Address by Prof. ${ }^{\circ}$. Marshall Ward, F.R.S., President of the Section. (Concluded.)

Geology at the British Association . . . . . . . . 478

Anthropology at the British Association . . . . 486

University and Educational Intelligence . . . . . 488

Scientific Serials . . . . . . . . . . . . 488

Societies and Academies

NO. I 455 , VOL. 56$]$ 